\title{
Allelopathic Interactions of Sunflower Mulch on Growth and Yield of Faba Bean and Mate Weeds
}

\author{
H. Hameed ${ }^{1}$, A. W. Shahwany ${ }^{2}$ \\ Department of Biology, College of Science, University of Baghdad, Baghdad, Iraq
}

\begin{abstract}
Mulching is an important agronomic practice in conserving the soil moisture and modifying the soil physical environment. Field experiment conducted during season of 2016/2017 to test the allelopathic influence of sunflower mulch, residue and herbicide on yield of faba bean and mate weeds. The field divided to two blocks. In spring 2016, the plots (4X 4$) \mathrm{m}$ in the first area cultured (C) with seeds of sunflower cv. Sin Altheeb, while the other one lifted without culture (non-culture) (NC). At the second growth season, some plots enclosed by dry plant material of sunflower, while the sunflower residues combined in some other plot soil. Other plots with label rate of herbicide (trifluralin) and plots without any treatments were involved in the experiment for comparison. These treatments replicated in both field area. Seeds of faba bean Vicia faba sown in rows at the beginning of October 2016 (in both filed area), keeping space $40 \mathrm{~cm}$ between rows and $20 \mathrm{~cm}$ between plants. The experiment conducted in randomized complete block design (RCBD) under split plot arrangement with four replications. The highest means of soil moisture $17.14 \%$ preserved under mulch treatment, while the lowest $2.87 \%$ preserved under herbicide. Treatment with Herbicide $(C N)$ had significantly inhibited weed density by $72.22 \%$ comparison to control. Herbicide (NC) had significantly improved the number of pods, seeds per pod and weight 100 seed by $52.17,13.61$ and 39.29 $\%$ over control, respectively. In addition, there wasn't any, significant differences between herbicide (NC) and Mulching (NC) in number of seeds/pod and weight 100 seeds. More works are need on using mulching for other crops under different environmental conditions. However, such work would help farmers to use this easily existing resource to manage weed and improve crop productivity and soil fertility in a sustainable manner.
\end{abstract}

Keywords: Allelopathic effect, companion weeds, faba bean, sunflower mulch

\section{Introduction}

Weed compition in field crops is a key issue causal to direct loss in quality and quantity of production, and weeds identified as the ubiquitous class of pests intrusive with crop plants through competition and allelopathy. Traditionally, weed management practices comprises preventative, mechanical, cultural, biological, and chemical tactics (9). However, with the hasty increase in the number of actual herbicides after 1960's, weed management methods have become more reliant on herbicides (27).

Allelopathy society distinct allelopathy as follows: The science that studies any process involving secondary metabolites produced by plants, micro-organisms, viruses, and fungi that effect growth and development of agricultural and biological systems (excluding animals) (26). Allelopathy refers to the beneficial or harmful effects of plants on each other. They careful as a step towards maintainable weed management. Such method could help in minimizing the toxic effects of current agricultural practices (20).

The word mulch has been probably derivative from the German word "molsch" means soft to decay, which apparently referred to the use of straw and leaves by gardeners as a spread over the ground as mulch (11). Mulch particularly reduces water loss from the soil arid and helps to retain stable soil temperature $(12,13)$. Mulch cover decreases surface runoff and grips rainwater at the soil surface there by giving it more time to penetrate into the soil (15).

Trifluralin is a herbicide used for the regulator of annual grasses and broad leaves weed in beans, brassicas, cotton, groundnuts, forage legumes, soybeans, sugar beet, sunflowers, tomatoes, and vineyards (25). A study results in the USA, trifluralin related with an increased risk for nonHodgkin lymphoma. In contrast, a study of ovarian cancer in Italy did not suggest a connotation with trifluralin exposure. In both studies, the numbers of bare subjects were small. A larger study in the USA showed no link with leukemia. (15).

Sunflower (Halianthus annuus L.) of family Asteraceae is a possible allelopathic plant enjoying a number of bioactive allelochemicals, which show allelopathic effects on other plants (16). Principal allelochemicals of sunflower are phenolic compounds, terpenoids and flavonoids $(17,7)$. The allelopathic properties of sunflowers are well recognized; their effects on many weeds and crops have been documented (16).

Faba bean is an annual legume, botanically known as Vicia faba L. (8). Faba bean is a leguminous crop grown in due to its economic position. Ethiopia is the second largest faba bean producer in the world next to China and accounts for about $12 \%$ of the world area and manufacture (19). Faba bean cannot only be grown on diver's agro-climatic conditions positively, but it can also be produced on residual soil moisture, moderately more tolerant to biotic and abiotic stress, with minimum input $(21,22)$. The present study conducted to assess the use of allelopathic sunflower mulch and residues with herbicides for weed control in faba bean crop grown under field environments, and investigate if the phenolics dynamic in soil contribute in the allelopathic potential of the incorporated sunflower residues in soil.

\section{Materials and Methods}

An experiment performed in the Botanical Garden, College of Science - University of Baghdad during the growing season of 2016. The field divided to two blocks. The first 


\section{International Journal of Science and Research (IJSR) \\ ISSN (Online): 2319-7064 \\ Index Copernicus Value (2015): 78.96 | Impact Factor (2015): 6.391}

one cultured(C) with seeds of sunflower cv. Sin Altheeb in 5th of May 2016, while the other one leaved without culture (NC). At the filed sunflower mulch, seeds of sunflower grown in lines within plots of $(5 \times 6) \mathrm{m}$, using $75 \mathrm{~cm}$ between lines and $20 \mathrm{~cm}$ within lines. All the agricultural management, such as fertilizers, irrigation and pest management applied as suggested for sunflower crop. At the physiological maturity, the seeds were harvested and the plants left on the plots to dry under sun. Based on field calculation, it was found that 12 mature plants of sunflower occupied $1 \mathrm{~m}^{2}$ area which is equivalent to 10 tons (t) of airdried tops per hectare (ha) of soil to the depth of $30 \mathrm{~cm}$. Therefore, residue, rates $10 \mathrm{t} / \mathrm{ha}$ used in this experiment to test their effects on growth and yield of faba bean crop and companion weeds as mulching treatments. Sunflower dried plant residue were add in to the plot soil at $10 \mathrm{t} / \mathrm{ha}$ (by leaving all plant residues on the surface of plot soil) (3). Seeds of faba bean manually sown at 22 of October 2016 with $40 \mathrm{~cm}$ spaced between rows and $20 \mathrm{~cm}$ within rows in plots computing $(1 \times 1) \mathrm{m}$ (in both field areas). Plots without sunflower mulch, residues and herbicide used as control. Nitrogen fertilizer as Urea $(46 \% \mathrm{~N})$ and phosphorus as triple super phosphate $\left(46 \% \mathrm{P}_{2} \mathrm{O}_{5}\right)$ used as recommended for faba bean crop. At physiological maturity of crop (120 days after sowing), Weed density was measured, then weeds were collected and dried at $70^{\circ} \mathrm{C}$ for 3 days. weeds population and biomass measured in $\mathrm{m}^{2}$. air-dried biomass, seed yield and yield components (number of pods per plant, weight of 100 seeds) of faba bean measured from randomly selected five samples following standard events. Total Phenols material measured using Emerson's pioneering oxidative coupling method (6). To the total volume $50 \mathrm{ml}$ contained $10 \mathrm{~mL}$ of $4 \mathrm{M}$ aqueous ammonia $0.1 \mathrm{~mL}$ of $3 \% 4-$ Amino antipyrene, $1 \mathrm{ml}$ of $2 \%$ potassium ferocyanate and $1 \mathrm{ml}$ of the samples. Phenolic materials react with 4aminoantipyrine in the presence of potassium ferricyanide at a $\mathrm{pH}$ of 10 to form a stable reddish-brown colored antipyrine dye. The amount of color produced is a function of the concentration of phenolic material. Soil samples taken from plots amended with $10 \mathrm{t}^{\mathrm{h}} \mathrm{ha}^{-1}$ mulching, residue, and herbicide and from plots without mulching, residue and herbicide (control) at a depth of $30 \mathrm{~cm}$ at 14, 28, 42, and 56 date to estimate.The soils mixed thoroughly and allowed to dry at room temperature for 3 days. Samples of $250 \mathrm{~g}$ dry soil extracted separately in $250 \mathrm{ml}$ of distilled water by shaking for $24 \mathrm{~h}$ at $200 \mathrm{rpm}$ (4). Soil suspensions filtered through Whatman No. 2 filter paper under vacuum. The mixture transferred to the separator funnel. The extraction carried out with $3 \mathrm{~mL}$ of chloroform (trichloromethane). The absorbance were measured against a blank of chloroform at the wave length of $460 \mathrm{~nm}$, using $1 \mathrm{~cm}$ cells. Calibration curve was accomplished using the same procedure on the samples, series of dilution of phenol standard solution ranged of (1.8-18.8) $\mathrm{mg} / \mathrm{L}$ (Figure 1) .The data were recorded on data sheet, slope and intercept were calculated and used in sample concentration calculation.

The experiment conducted using split plot design with four replicates. The plots of sunflower were keeping in the main plots while mulch, residues with sunflower, herbicides and Weedy check (Control) were assigning to subplots. The data were analyzed by analysis of variance (ANOVA) using gene stat computer software package. Mean values were compared using least significant difference (LSD) at $P \leq 0.05$ probability level.

\section{Result and Discussion}

Total phenolic in field soil significantly increased after combination of sunflower residues and touched their peak at 4 weeks of residues decay, then decreased significantly at 6 weeks and disappeared at 8 weeks (Figure 1 and table 1).

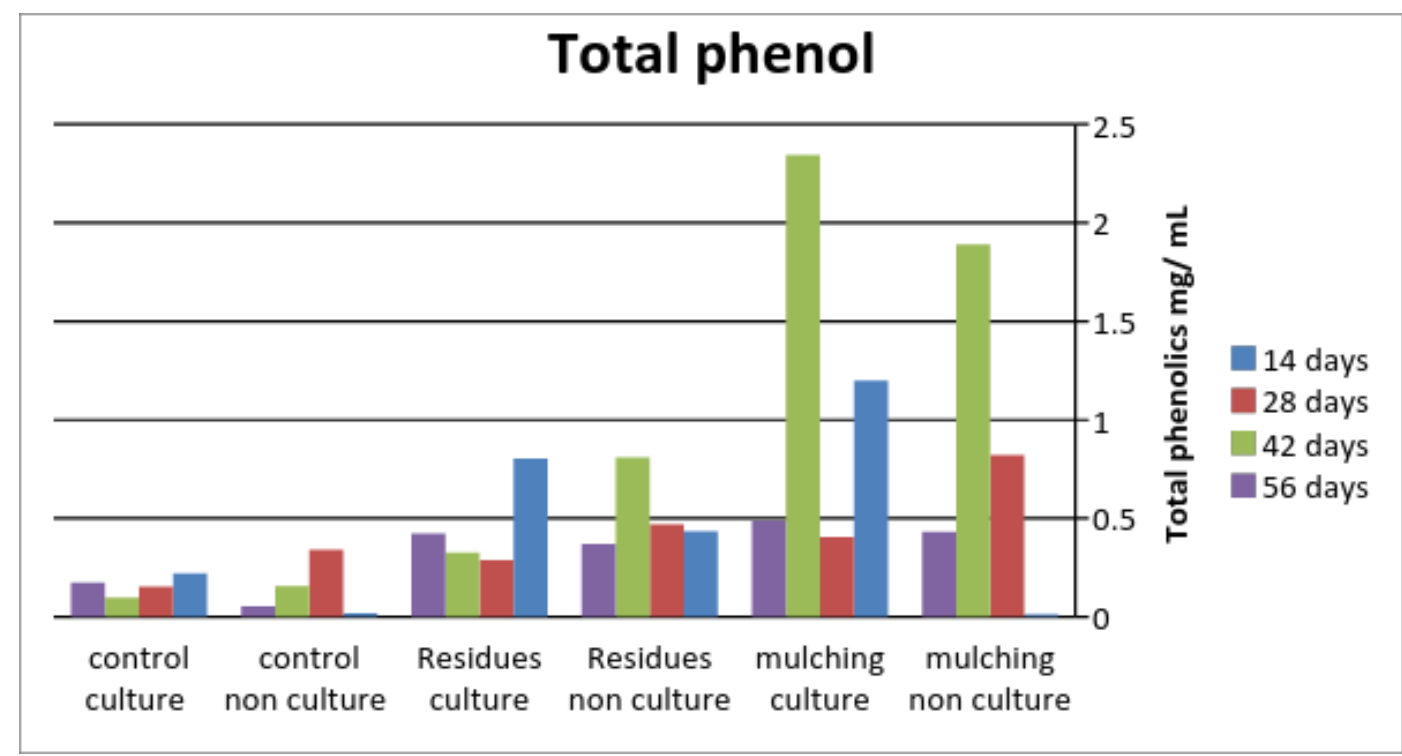

Figure 1: Total phenolics release in culture and non-culture field soil amended with sunflower Residues and mulch during different decomposition periods 


\section{International Journal of Science and Research (IJSR) \\ ISSN (Online): 2319-7064 \\ Index Copernicus Value (2015): 78.96 | Impact Factor (2015): 6.391}

Table 1: Total concentration of phenolics acids release in culture field soil amended with sunflower residues and mulch at different decomposition periods

\begin{tabular}{|c|c|c|c|c|c|c|c|c|}
\hline \multirow{4}{*}{ Treatment } & \multicolumn{8}{|c|}{ Determination of total phenolics } \\
\hline & \multicolumn{8}{|c|}{ Weeks } \\
\hline & \multicolumn{2}{|c|}{2} & \multicolumn{2}{|c|}{4} & \multicolumn{2}{|c|}{6} & \multicolumn{2}{|c|}{8} \\
\hline & $\mathrm{NC}$ & $\mathrm{C}$ & $\mathrm{NC}$ & $\mathrm{C}$ & $\mathrm{NC}$ & $\mathrm{C}$ & $\mathrm{NC}$ & $\mathrm{C}$ \\
\hline Weedy check (Control) Culture & 0.019 & 0.221 & 0.156 & 0.34 & 0.099 & 0.156 & 0.054 & 0.175 \\
\hline Mulch Culture & 0.012 & 1.198 & 0.406 & 0.821 & 1.89 & 2.345 & 0.431 & 0.488 \\
\hline Residues Culture & 0.435 & 0.805 & 0.287 & 0.469 & 0.306 & 0.81 & 0.369 & 0.423 \\
\hline L.S.D. $\leq 0.05$ & \multicolumn{2}{|c|}{0.003} & \multicolumn{2}{|c|}{0.0057} & \multicolumn{2}{|c|}{0.008} & \multicolumn{2}{|c|}{0.0012} \\
\hline
\end{tabular}

The phenolic increased with the increased sunflower residue combined in to the field soil. In addition, the attentiveness of phenolic increased in culture plots computer with nonculture.

Soil moisture from (NC) plots take to know the result of mulching and residues contrast to herbicide on loss moisture from soil. Mulching had highly significant difference on soil moisture content. The highest means of soil moisture $(17.14 \%)$ preserved under mulch treatment, while the lowest $(2.87 \%)$ preserved under herbicide. During 42 days after sowing, the highest soil moisture $(29 \%)$ conserved under mulching, while the lowest soil moisture content (23\%) under herbicide (Table 2).

Table 2: Soil moisture percentage after two day from irrigation $(42,56$ and 76 days)

\begin{tabular}{|c|c|c|c|c|}
\hline \multirow{2}{*}{ Treatment } & \multicolumn{4}{|c|}{ Soil moisture take from (NC) plots. } \\
\cline { 2 - 5 } & 42 days & 56 days & 76 days & Mean \\
\hline Weedy check(Control) & 25.00 & 23.00 & 22.00 & 23.33 \\
\hline Mulch & 29.00 & 27.00 & 26.00 & 27.33 \\
\hline Residues & 27.00 & 26.00 & 26.00 & 26.33 \\
\hline Herbicide & 23.00 & 25.00 & 24.00 & 24.00 \\
\hline Mean & 26 & 25.25 & 24.5 & \\
\hline LSD $\leq 0.05$ & 1.132 & 1.634 & 1.648 & \\
\hline
\end{tabular}

The result in table (3) showed that weed flora dominated the experimental site included several narrow and broad leaf weeds. Treatment with Herbicide (NC) and (C) had significantly inhibited weed density by 72.22 and $66.66 \%$ over weedy check (Table 3 ).

Table 3: Effects of sunflower residues, mulch and herbicide applied on weeds density and Reduction \% growing within faba bean under field conditions

\begin{tabular}{|c|c|c|}
\hline Treatment & $\begin{array}{c}\text { Weed density } \\
\text { (plants } / \mathrm{m}_{2} \text { ) }\end{array}$ & $\begin{array}{c}\text { Reduction } \\
\%\end{array}$ \\
\hline Weedy check (C) (control) & 15.00 & \\
\hline Mulch (C) & 8.00 & 46.66 \\
\hline Residues (C) & 10.00 & 33.33 \\
\hline Herbicide (C) & 5.00 & 66.66 \\
\hline Weedy check (NC)(control) & 18.00 & \\
\hline Mulch (NC) & 9.00 & 50 \\
\hline Residues (NC) & 14.00 & 22.22 \\
\hline Herbicide (NC) & 5.00 & 72.22 \\
\hline LSD $\leq 0.05$ & 1.491 & \\
\hline
\end{tabular}

Concerning on crop yield, all treatments (sunflower mulch, residues and herbicide) had significantly increased seed yield of faba bean crop over control (Table 4). The highest seeds yield and dry weight biomass (71.84 and 51.00) recorded with herbicide (NC) treatment while the lowest seeds yield and dry weight biomass (37.36 and 40.66) recorded at control (NC) treatment.

Table 4: Effects of sunflower residues, mulch and herbicide applied on seed yield and dry weight biomass of faba bean grown under field conditions

\begin{tabular}{|c|c|c|c|c|}
\hline \multirow{2}{*}{ Treatment } & \multicolumn{2}{|c|}{ Seeds yield (t/ha) } & Dry weight biomass (t/ha) \\
\cline { 2 - 5 } & $\begin{array}{c}\text { Non-culture } \\
\text { (NC) }\end{array}$ & $\begin{array}{c}\text { Culture } \\
\text { (C) }\end{array}$ & $\begin{array}{c}\text { Non-culture } \\
\text { (NC) }\end{array}$ & $\begin{array}{c}\text { Culture } \\
(\mathrm{C})\end{array}$ \\
\hline $\begin{array}{c}\text { Weedy check } \\
\text { (Control) }\end{array}$ & 37.36 & 37.34 & 40.66 & 40.66 \\
\hline Mulch & 45.5 & 43.26 & 40 & 41 \\
\hline Residues & 47.36 & 42.12 & 37 & 45 \\
\hline Herbicide & 71.84 & 45.46 & 51 & 41.66 \\
\hline LSD $\leq 0.05$ & \multicolumn{2}{|c|}{4.836} & \multicolumn{2}{|c}{4.257} \\
\hline
\end{tabular}

Herbicide (NC) had significantly enhanced the number of pods per plant, seeds per pod and weight 100 seed by 52.17, 13.61 and $39.29 \%$ over control (Table 5), respectively. While there was not any, significant differences between herbicide (NC) and Mulching (NC) in number of seeds /pod and weight 100 seeds.

Table 5: Effects of sunflower mulch, residues and herbicide applied on number of pods/plant and seeds/pod and weight of 100 seeds of faba bean grown under field conditions.

\begin{tabular}{|c|c|c|c|c|c|c|}
\hline \multirow{2}{*}{ Treatment } & \multicolumn{6}{|c|}{ Yield components } \\
\cline { 2 - 7 } & $\begin{array}{l}\text { Number of } \\
\text { pods/plant }\end{array}$ & $\begin{array}{c}\text { Number of } \\
\text { seeds/pod }\end{array}$ & weight 100 seeds (g) \\
\cline { 2 - 7 } & NC & C & NC & C & NC & C \\
\hline $\begin{array}{c}\text { Weedy check } \\
\text { (control) }\end{array}$ & 23 & 18.33 & 71 & 57 & 346.9 & 268.5 \\
\hline Mulch & 25 & 19 & 71.33 & 40 & 483.2 & 302 \\
\hline Residues & 21 & 19 & 70.33 & 43 & 347.2 & 259.7 \\
\hline Herbicide & 35 & 19.33 & 80.67 & 48.67 & 479.4 & 262.6 \\
\hline LSD $\leq 0.05$ & 6.288 & 21.056 & \multicolumn{5}{|c|}{80.89} \\
\hline
\end{tabular}

The data of the study revealed that sunflower residues applied as a mulch to the field soil reduced weed density and dry biomass and that the decrease with the increase of sunflower residue rate. The conquest of weed density and biomass could accredited to different mechanisms such as change in soil physical environment and the issue of chemicals (6). In fact, sunflower residue stated to release different allelopathic compounds such as phenolics (1, 2, 5, 23). Request of sunflower residues as a mulch not only measured weed, but also enhanced yield of faba bean. The enhancement of yield may attributed to the decrease in weed residents, weed growth and to the improvement of physical, chemical, biological, and nutritional possessions of preserved soil. It has been described that weed control when using a cover crop is reliant on the amount of biomass left at soil surface which disturbs soil chemical and physical properties 


\section{International Journal of Science and Research (IJSR) \\ ISSN (Online): 2319-7064}

Index Copernicus Value (2015): 78.96 | Impact Factor (2015): 6.391

and makes more positive environment for root development and enhanced plant growth and yield $(3,10,18,24)$. More work is essential on other cover crops under different environmental conditions. However, such work would help farmers to use this easily offered supply to manage weed and advance crop efficiency and soil fertility in a maintainable method.

\section{References}

[1] Alkateeb, T. 2014. Allelopathic Potential of Two Sorghum Cultivars on Weeds, Mung Bean and Symbiotic Nitrogen Fixation and Possible Rapid Identification of Allelopathic Potential by PCR Technique. Ph.D.Dissertcaion in Botany (Plant Physiology), College of Science, University of Baghdad, Iraq. pp:119.

[2] Alsaadawi, I. and F. Dayan, 2009. Potential and prospect of sorghum allelopathy in agroecosystem. Allelopathy Journal 24: 255-270.

[3] Alsaadawi, I., A. Khaliq, N.R., Lahmood, and A. Matloob, 2013. Weed management in broad bean (Vicia faba L.) through allelopathic Sorghum bicolor (L.) Moench residues and reduced rate of a pre-plant herbicide. Allelopathy Journal 32: 203-212.

[4] Ben - Hammouda, M., J. K. Robert, C. M. Harry and M. Sarwar, 1995. A Chemical basis for differential allelopathic potential of sorghum hybrids on wheat. Journal of Chemical Ecology 21:775-786.

[5] Cheema, Z.A., A. Khaliq and M. Farooq, 2008. Sorghum Allelopathy for Weed Management in Wheat In: Allelopathy in Sustainable Agriculture and Forestry, Springer, New York, USA. pp: 255-270.

[6] Ferreira, M. and C. Reinhardt, 2016. Allelopathic weed suppression in agroecosystems: A review of theories and practices. African Journal of Agricultural Research 11: 450-459.

[7] Gawronska, H., D. Ciarka, W. Bernat and S.W. Gawronski. 2007. Sunflower Desirable Allelopathic Crop for Sustainable and Organic Agriculture. In: New Concepts and Metrology in Allelopathy. (Eds.): Fujii, Y. and S. Hiradate.Science Publishers, Inc., Enfield, NH, pp: $185-210$.

[8] Harlan, J.R. 1969. Ethiopia: A Centre of diversity. Econ. Bot. 23:309-314

[9] Harker, K. N. and J. T. O’Donovan. 2013. Recent Weed Control, Weed Management, and Integrated Weed Management. Weed Technology 27:1-11.

[10] Hobbs, P., K. Sayre and R. Gupta. 2008. The Role of Conservation Agriculture in Sustainable Agriculture. Philosophical Transactions of the Royal Society B: Biological Sciences 363: 543-555.

[11] Jacks, C. V. ,W. D. Brind and R. Smith. 1955. Mulching Technology Comm., No. 49, Common Wealth. Bulletin of Soil Science pp:118.

[12]JI S., and P.W. Unger P.w. 2001. Soil water accumulation under different precipitation, potential evaporation and straw mulch conditions. Soil Sci. Soc. of Amer. 1. 65: 442-448.

[13] Kar G. and A. Kumar. 2007. Effects of irrigation and straw mulch on water use and tuber yield of potato in Eastern India. Agriculture Water Management 94: 109116.
[14] Khurshid, K., M. Iqbal, M. S. Arif, and A. Nawaz. 2006. Effect of tillage and mulch on soil physical properties and growth of maize. International Journal of Agriculture and Biology, 8: 593-596.

[15]Lyon. 1991 . International Agency for Research on Cancer. Occupational exposures in insecticide application, and some pesticides. (IARC Monographs on the Evaluation of Carcinogenic Risks to Humans 53: 515-534.

[16] Macias, F.A., R.M. Varela, A. Torres, J.L.G. Galindo and J.M.G. Molinillo. 2002. Allelochemicals from Sunflowers: Chemistry, Bioactivity and Applications. In 'Chemical Ecology of Plants: Allelopathy of Aquatic and Terrestrial Ecosystems'. (Eds.): Inderjit, A.U. Mallic. pp: 73-88.

[17] Macias, F.A., A. Lopez, R.M. Varela, A. Torres and J.M.G. Molinillo. 2004. Bioactive apocarotenoids annuionones $\mathrm{F}$ and $\mathrm{G}$ : structural revision of annuionones A, B and E. Phytochem., 65: 3057-3063.

[18] Mohammadi, G. 2012. Living mulch as a Tool to Control Weeds in Agroecosystems: A Review. In: Weed Control, In Tech Press, Croatia. pp: 75-100.

[19] Mussa, J. and K. Gemechu, 2006 . Vicia faba L. In M. Brink and G. Belay (Eds.), prate 1: Cereals and pulses/Céréales et légumes secs [CD-Rom]. PROTA: Wageningen.

[20] Mulvaney, M., A. Price and W. Wood. 2011. Cover crop residue and organic mulches provide weed control during limited-input notill collard production. Journal of Sustainable Agriculture 35: 312-328.

[21] Singh, A.K. and K. Prevesh. 2009. Nutrient management in rainfed dryland agro eosystemin the impending climate change scenario. Agric. Situation in India 4 (5):265-270.

[22] Singh, A. K. and B.P. Bhatt 2012a. Faba Bean (Vicia faba L.): A Potential leguminous crop .pp: 518.

[23] Weston, L. 1996. Utilization of allelopathy for weed management in agroecosystems. Agronomy Journal 88: 860-866.

[24] Weston, L.A., I.S. Alsaadawi, and S.R. Baerson. 2013. Sorghum allelopathy-from ecosystem to molecule. Journal of Chemical Ecology 39: 142-153.

[25] Xuan, T.D., S. Tawata, T.D. Khanh and I.M. Chung. 2005. Decomposition of allelopathic plants in soil. Journal of Agronomy and Crop Science. 191: 162-171.

[26]Zhang, W., F. Jiang and J. Ou. 2011. Global pesticide consumption and pollution: with China as a focus. Proceedings of the International Academy of Ecology and Environmental Sciences 1:125-144. 